\title{
Ballast water treatment by sequential filtration and advanced oxidation process
}

\author{
Donghai $W U^{1} \&$ Guanghua $L^{1, a}$ \\ Ran Zhang ${ }^{2}$ \\ ${ }^{1}$ Key Laboratory of Integrated Regulation and Resource Development on Shallow Lakes of \\ Ministry of Education, College of Environment, Hohai University, Nanjing 210098, China. E-mail \\ address: wdh1018@hhu.edu.cn \\ ${ }^{2}$ State Key Laboratory of Urban Water Resource and Environment, Harbin Institute of Technology, \\ P.O. Box 2606, 202 Haihe Road, Harbin 150090, China
}

KEYWORD: Ballast water; filtration; UV/Ag- $\mathrm{TiO}_{2} / \mathrm{O}_{3}$ oxidation; inactivation ABSTRACT: The ability of a 2-stage (filtration $+\mathrm{UV} / \mathrm{Ag}-\mathrm{TiO}_{2} / \mathrm{O}_{3}$ ) ballast water treatment process to control non-indigenous species introduction has been assessed. The removal efficiencies of turbidity and phytoplankton were monitored during the filtration pretreatment phase, and the degradation of phytoplankton (Dunaliella salina and Phacodactylum tricornutum) chlorophyll $a$ (chl-a) by $\mathrm{UV} / \mathrm{Ag}-\mathrm{TiO}_{2} / \mathrm{O}_{3}$ were investigated. Results showed that $50 \mu \mathrm{m}$ screen filtration could remove a small part of phytoplankton, and reduce the turbidity. Compared to individual unit processes with ozone or UV/Ag- $\mathrm{TiO}_{2}$, the removal of chl- $a$ by the combined $\mathrm{UV} / \mathrm{Ag}-\mathrm{TiO}_{2} / \mathrm{O}_{3}$ process was enhanced, and the effluent exhibited a persistence toxicity within $24 \mathrm{~h}$. The results indicate that a combination of filtration and $\mathrm{UV} / \mathrm{Ag}-\mathrm{TiO}_{2} / \mathrm{O}_{3}$ advanced oxidation maybe a promising method for ballast water treatment.

\section{INTRODUCTION}

Ballast water is essential for ships without sufficient weight of cargo to ensure their balance and structural integrity during voyage. Nevertheless, ships transporting ballast water has been recognized as a major pathway for the spread of aquatic organisms into new habitats (Stehouwer et al. 2015). It is estimated that annually about 10 billion tons of ballast water are transferred globally, and more than 3000 species are transported by ships each day (Banerji et al. 2012). To prevent the introduction of potentially invasive species, regulations for the control and management of ballast water was drafted and ratified by the International Maritime Organization (IMO) in February 2004. According to the Regulation D-2 ballast water discharge standard, the organism concentrations in the discharge of ballast water should be below specified limits (Gollasch et al. 2007): less than 10 viable organisms $/ \mathrm{m}^{3}$ for minimum dimension greater than $50 \mu \mathrm{m}$; less than 10 viable organisms $/ \mathrm{mL}$ for the minimum dimension between 10 and $50 \mu \mathrm{m}$; Escherichia coli less than $250 \mathrm{cfu} / 100 \mathrm{~mL}$, intestinal Enterococci less than $100 \mathrm{cfu} / 100 \mathrm{~mL}$ and Toxicogenic Vibrio cholerae (O1 and O139) less than $1 \mathrm{cfu} / 100 \mathrm{~mL}$ or less than $1 \mathrm{cfu} / \mathrm{gram}$ wet wt. zooplankton samples.

Various technologies for ballast water treatment have been developed (Boldor et al. 2008), including filtration separation, ballast water heating, ultraviolet (UV) irradiation, electrochemical treatment, and chemical biocides. However, a single technique is not suitable for ballast water treatment when considering the efficiency and safety. Combinations of several methods, which can be more effective than one method standing alone, have been the focus of current researches for ballast water treatment. Recently, primary separation combined with secondary inactivation is emerging as a promising ballast water treatment technology, and filtration is proposed for separation of sediments and organisms from ballast water. Filtration is effective for removing zooplankton, while for bacteria and viruses it cannot reduce them. The removal efficiency of phytoplankton by filtration is complexly as the organisms size are various (Tsolaki \& Diamadopoulos 2010).

Ozonation and UV irradiation are the most frequently used methods for water disinfection. However, using these two methods separately, relatively high ozone doses and long UV treatment durations 
are required to eliminate the vast majority of species in ballast water. Photocatalytic ozonation $\left(\mathrm{UV} / \mathrm{TiO}_{2} / \mathrm{O}_{3}\right)$ has been reported as a promising disinfection technology that does not produce halogenated compounds. The application of ozone in combination with titanium dioxide photocatalysis $\left(\mathrm{UV} / \mathrm{TiO}_{2} / \mathrm{O}_{3}\right)$ brings about enhanced oxidative degradation of pollutants by the generation of highly reactive hydroxyl radical $(\cdot \mathrm{OH})$, which eventually leads to higher oxidation rates (Agustina et al. 2005).

The primary goals of this study was to examine the potential of filtration pretreatment combined $\mathrm{UV} / \mathrm{Ag}-\mathrm{TiO}_{2} / \mathrm{O}_{3}$ oxidation to treat ballast water. The removal of turbidity and phytoplankton by filtration was investigated, and the inactivation efficiency of $\mathrm{UV} / \mathrm{Ag}-\mathrm{TiO}_{2} / \mathrm{O}_{3}$ on phytoplankton were studied.

\section{MATERIALS AND METHODS}

\section{Preparation of artificial seawater and test culture}

All experiments were conducted in artificial seawater prepared using procedures reported previously (Wu et al. 2011). Pure culture Dunaliella salina (D. salina), and Phacodactylum tricornutum (P. tricornutum) were used as the indicator organisms in this study. The cultures were enriched in Guillard's f/2 medium, according to the procedures described elsewhere (Wu et al. 2011). Cells for further tests were harvested in their logarithmic growth phase, which was diluted with artificial seawater for testing .

\section{Ballast water treatment experiments}

Experiments were carried out in a laboratory ballast water treatment system, which consisted of a $120 \mathrm{~L}$ capacity feed tank, centrifugal pump, flowmeter, $50 \mu \mathrm{m}$ screen filter, venture injector, and the sterilization reactor ( $46 \mathrm{~mm}$ inner diameter, $540 \mathrm{~mm}$ height) with a water distributor at the bottom. The pumped raw water from the feed tank firstly went through the filter, and then passed through the venture injector, where ozonized gas that was generated from dry oxygen by a laboratory ozone generator was fed into water. Thereafter, the water went into the inactivation reactor. A quartz tube (30 $\mathrm{mm}$ diameter, $540 \mathrm{~mm}$ height) holding a low pressure UV-C lamp was placed at the center of the reactor. The $\mathrm{Ag}-\mathrm{TiO}_{2}$ thin film was coated on the inner surface of the reactor. The water flow rate was $500 \mathrm{~L} / \mathrm{h}$, corresponding with hydraulic residence time (HRT) of $0.5-3.0 \mathrm{~s}$ at different sampling ports. $0.02 \mathrm{~mL}$ of $0.1 \mathrm{~mol} / \mathrm{L} \mathrm{Na}_{2} \mathrm{~S}_{2} \mathrm{O}_{3}$ in $1 \mathrm{~mL}$ sample was previously added into the sampling pipe to stop the inactivation reaction by residual oxidant. To determine the toxicity of effluent, the samples were then stored in a dark airtight incubator, and chl- $a$ concentration was periodically measured.

\section{Analytical method}

The chl-a concentration was determined using the spectroscopic method (APHA, 1998). Photosynthetic activities of algal cells were measured by oxygen method (APHA, 1998). Absorbance at 254 $\mathrm{nm}\left(\mathrm{A}_{254}\right)$ was recorded with a spectrophotometer (T6, Beijing Purkinje General Instrument Co., Ltd., China). UV-C intensity on the outer surface of the quartz tube was measured by a UV irradiance meter (Photoelectric Instrument Factory of Beijing Normal University, China). Ozone supply was measured with an ozone monitor (MP, Anseros, Germany).

\section{RESULTS AND DISCUSSION}

\section{Effectiveness of filtration}

Chl-a, photosynthetic activity, $\mathrm{A}_{254}$, and turbidity of the simulated ballast waster contained various D. salina cells were characterized to assess the filtration efficiency (Fig. 1). Approximately $12 \%$ of the chl-a was removed (Fig. 1a), indicating that $50 \mu \mathrm{m}$ screen filtration could remove a small part of D. salina cells. The obtained photosynthetic activity reducing was about $10 \%$ (Fig. 1b), which is corresponding to the reductions of chl-a, and implied that $D$. salina cells would not be injured by filtration. On the other hand, about $20 \%$ turbidity removal was detected (Fig. 1c), suggesting that filtration pretreatment could improve water clarity of incoming ballast water. Turbidity can signifi- 
cantly influence the photo-induced disinfection efficiency. The above observation showed that filtration pretreatment has the potential for improving the efficiency of followed UV/Ag- $\mathrm{TiO}_{2} / \mathrm{O}_{3}$ inactivation.

It is noted that when organic materials presence in ballast water, the treatment efficiency will be reduced. In this work, some organic materials that contained in the cultures could be introduced into the testing water, and the change of $\mathrm{A}_{254}$ was monitored. However, only about $5 \%$ removal was obtained (Fig. 1d), suggesting that dissolved organic matter (DOM) could not be removed by filtration.
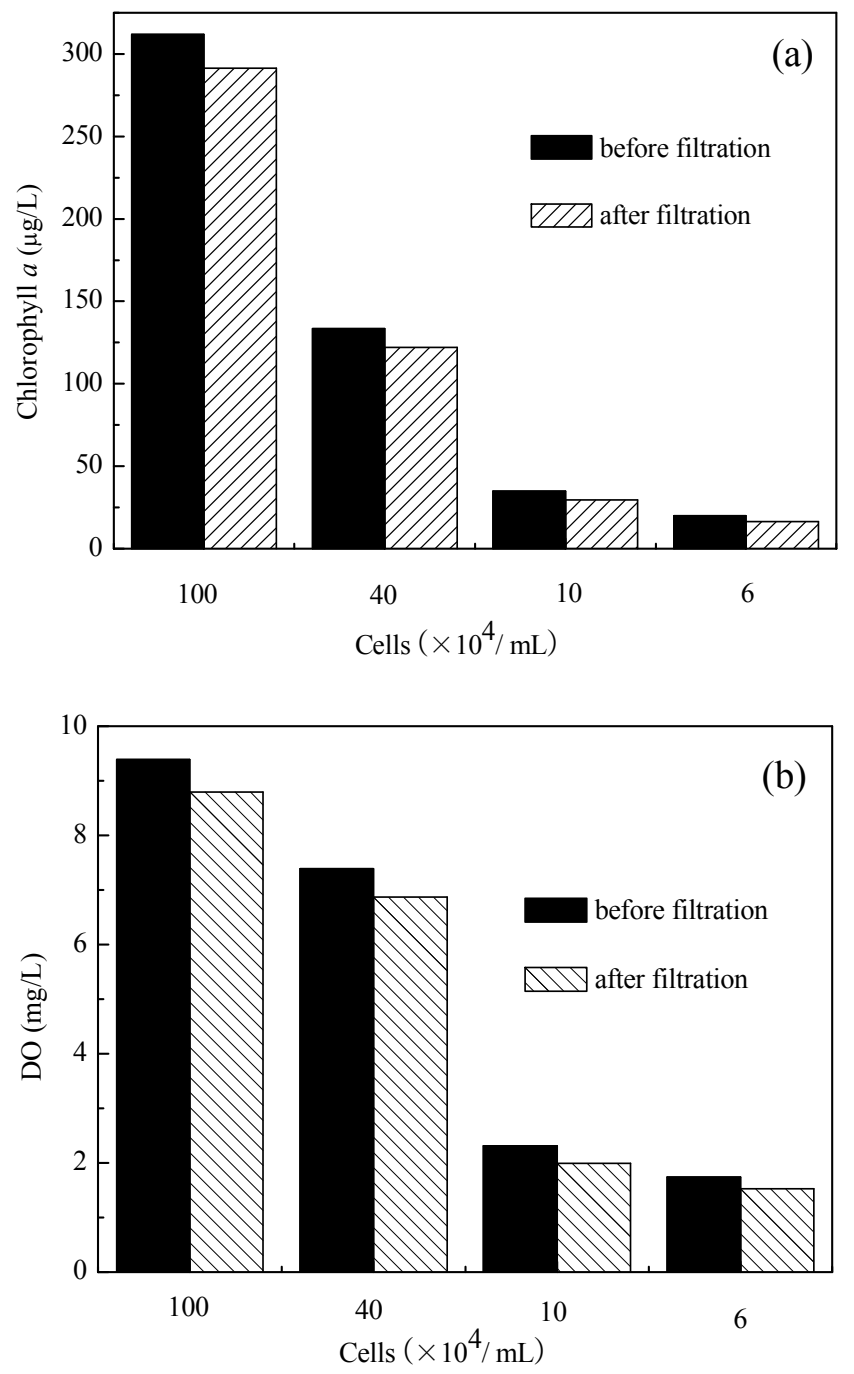

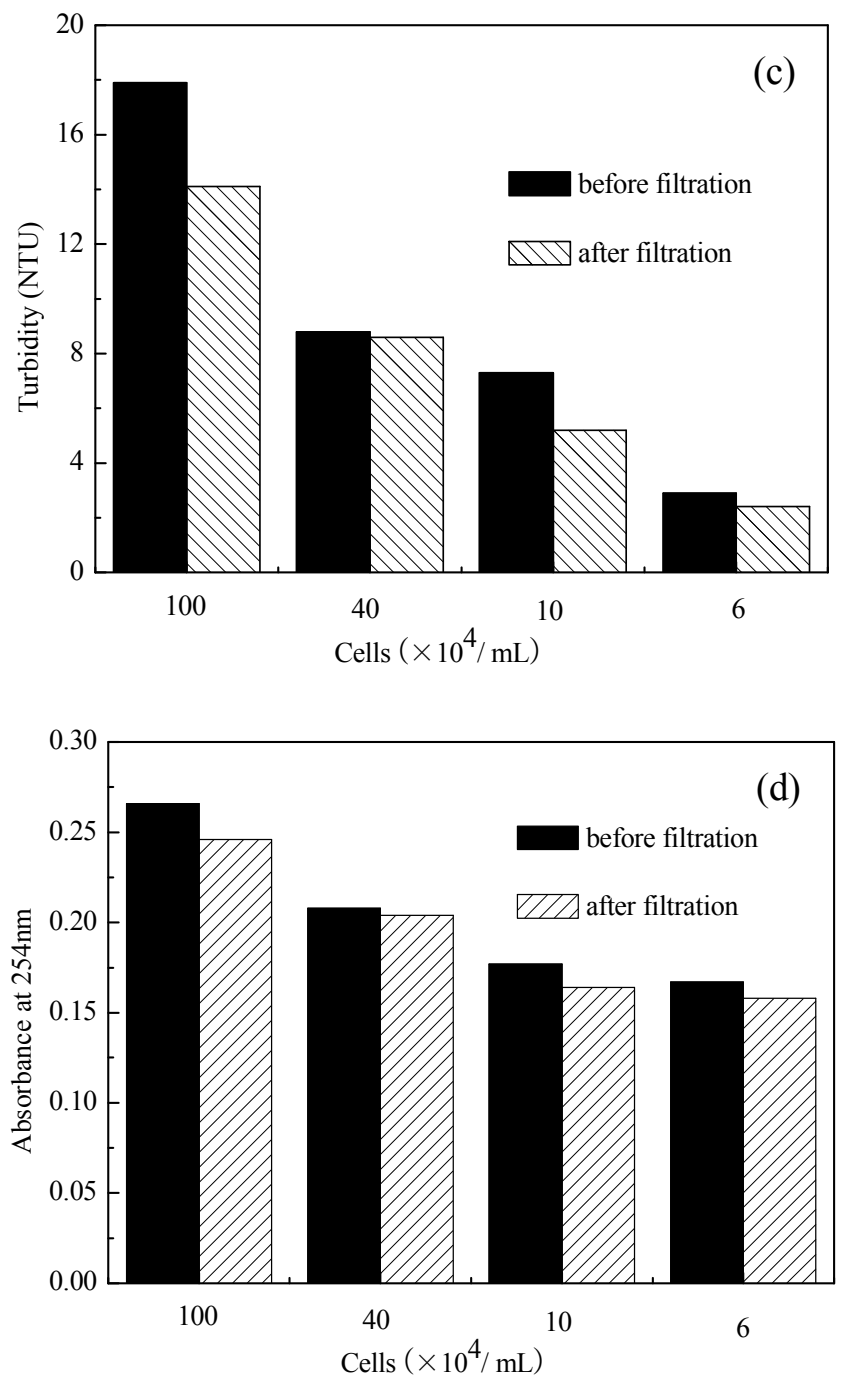

Figure 1. Effects of filtration on the treatment of D. salina containing ballast water: (a) chlorophyll $a$ concentration, (b) gross photosynthesis, (c) turbidity, (d) absorbance at $254 \mathrm{~nm}$

\section{Inactivation tests}

One important aspect of a prospective ballast water treatment is that it should be effective against a wide range of organisms. In an effort to optimize a practical and environmentally acceptable method of treating ballast water, the present study tests the efficacies of $\mathrm{UV} / \mathrm{Ag}-\mathrm{TiO}_{2} / \mathrm{O}_{3}$ treatment on the inactivation of $D$. salina and $P$. tricornutum. In experiments, $4.9 \mathrm{~g} / \mathrm{h}$ of ozone was initially injected into the reactor and UV intensity was fixed at $6.5 \mathrm{~mW} / \mathrm{cm}^{2}$. As shown in Figure 2, the UV/Ag-TiO 2 process was not effective in algae chl-a degradation. With HRT of $3.0 \mathrm{~s}$, only about $5.9 \%$ and $13.9 \%$ chl-a removal were detected for $D$. salina and $P$. tricornutum, respectively. In contrast, ozonation treatment rapidly removed chl-a, and combination of $\mathrm{UV} / \mathrm{Ag}-\mathrm{TiO}_{2}$ together with ozone further improved treatment efficiency. These observations were agreement with our previous studies (Wu et al. 2011), which suggested that the excess production of $\bullet \mathrm{OH}$ in the combined $\mathrm{UV} / \mathrm{Ag}-\mathrm{TiO}{ }_{2} / \mathrm{O}_{3}$ process maybe a possible explanation for the enhanced biological efficiency. 

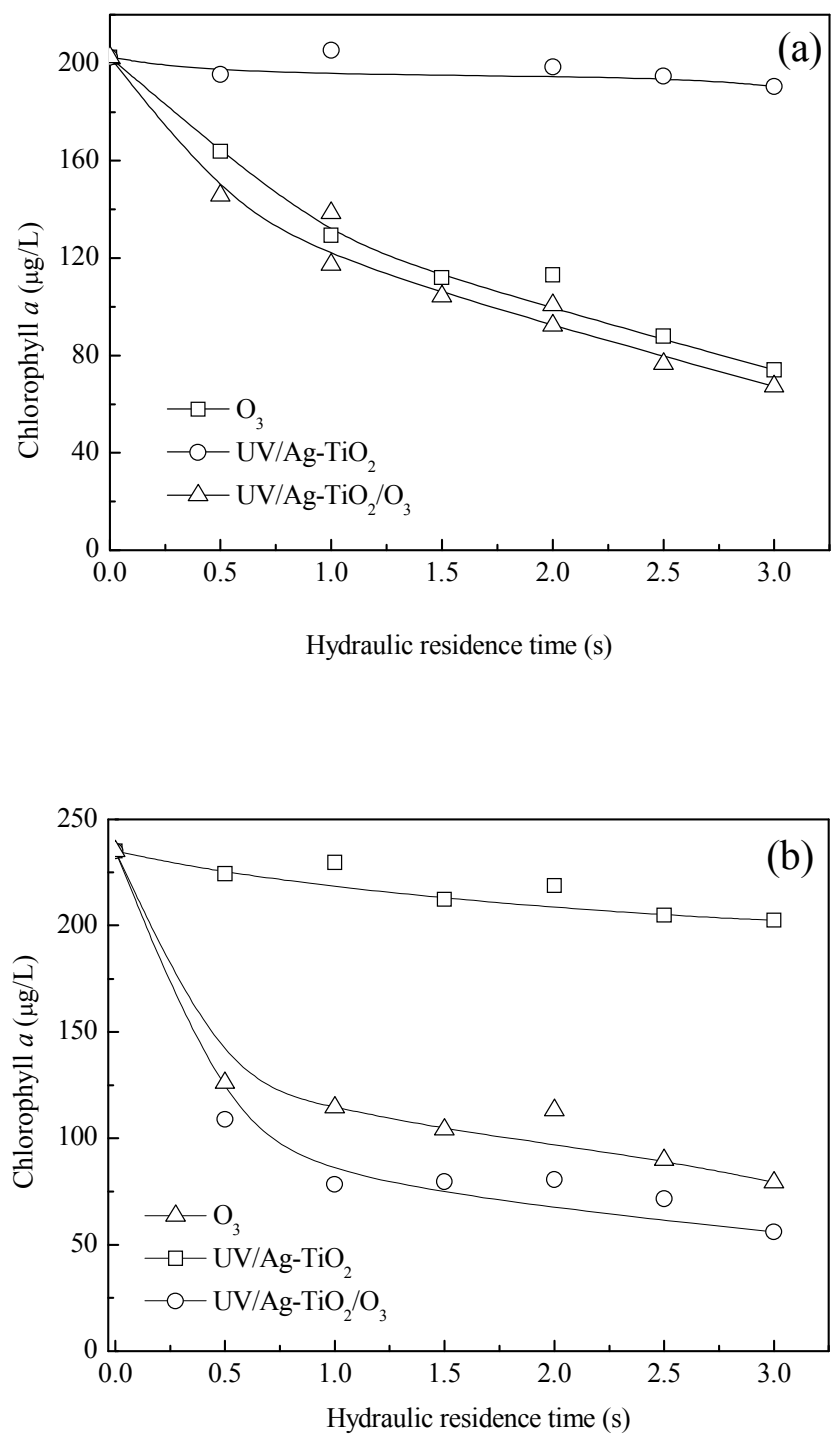

Figure 2. Degradation profiles of phytoplankton chlorophyll a for the different processes: (a) $D$. $s a$ lina; (b) P. tricornutum

\section{Toxicity of effluent}

After treatment by sequential filtration and UV/Ag- $\mathrm{TiO}_{2} / \mathrm{O}_{3}$ process, the toxicity of the effluent was investigated. As shown in Figure 3, the algae chl-a concentration decreased with stored time, especially in the initial $4 \mathrm{~h}$. After $24 \mathrm{~h}$, the chl-a concentrations of D. salina and P. tricornutum decreased from 67.3 and $56.0 \mu \mathrm{g} / \mathrm{L}$ to 21.2 and $28.1 \mu \mathrm{g} / \mathrm{L}$, respectively.

UV radiation is a clean technology that exhibits high efficiency for bacteria inactivation. However, ballast water treatment by UV radiation or photocatalysis alone during ballasting maybe requested to be secondary treated during deballasting, owing to the reactivation and multiplication of microorganisms in ballast tank (Martinez et al. 2013). The results in Figure 3 implied that application of $\mathrm{UV} / \mathrm{Ag}-\mathrm{TiO}_{2}$ and ozonation simultaneously could overcome the drawbacks of sole UV radiation. 


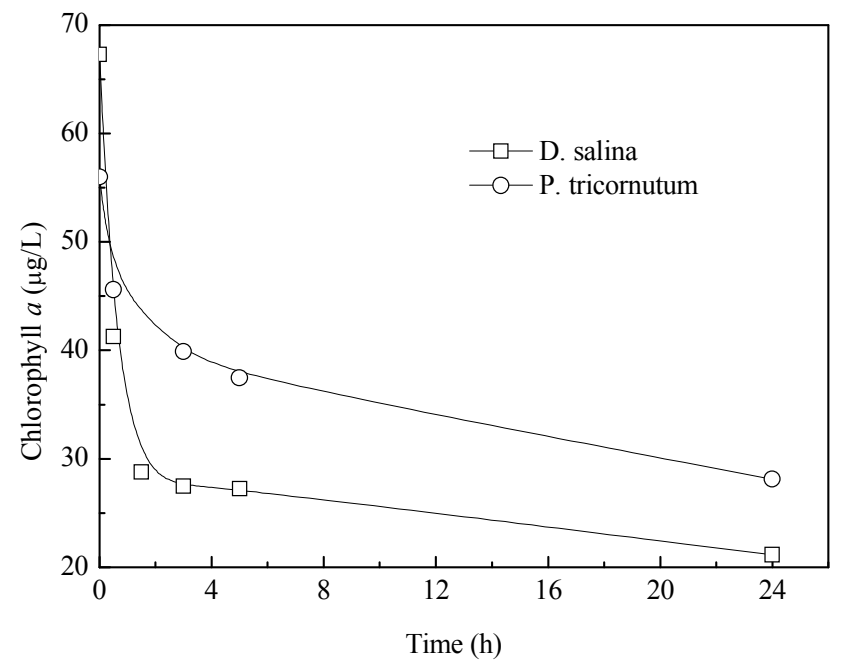

Figure 3. Decay of remaining phytoplankton chl-a in effluent with time

\section{CONCLUSIONS}

This study revealed that sequential filtration and $\mathrm{UV} / \mathrm{Ag}-\mathrm{TiO}_{2} / \mathrm{O}_{3}$ oxidation process was efficient for ballast water treatment. Screen filtration $(50 \mu \mathrm{m})$ pretreatment could improve the clarity of incoming ballast water, which may enhance the efficiency of the followed inactivation process. Combination of ozonation and $\mathrm{UV} / \mathrm{Ag}-\mathrm{TiO}_{2}$ yield higher chl-a removal efficiency than sole ozonation and $\mathrm{UV} / \mathrm{Ag}-\mathrm{TiO}_{2}$, and the effluent exhibited a persistence toxicity within $24 \mathrm{~h}$. It is concluded that sequential filtration and $\mathrm{UV} / \mathrm{Ag}-\mathrm{TiO}_{2} / \mathrm{O}_{3}$ process has the potential for ballast water treatment.

\section{ACKNOWLEDGMENTS}

We are grateful for grants from Natural Science Foundation of Jiangsu Province (No. BK20130835), China Postdoctoral Science Foundation (No. 2013M541600), Fundamental Research Funds for the Central Universities of Hohai University (No. 2013B13020026), and A Project Funded by the Priority Academic Program Development of Jiangsu Higher Education Institutions.

\section{REFERENCES}

[1] Agustina T. E., Ang H. M.\&Vareek V. K. 2005. A review of synergistic effect of photocatalysis and ozonation on wastewater treatment. Journal of Photochemistry and Photobiology C-Photochemistry Reviews 6 (4): 264-273.

[2] American Public Health Association (APHA). 1998. Standard methods for the examination of water and wastewater, 20th ed., Washington, DC

[3] Banerji S., Werschkun B.\&Hofer T. 2012. Assessing the risk of ballast water treatment to human health. Regulatory Toxicology and Pharmacology 62 (3): 513-522.

[4] Boldor D., Balasubramanian S., Purohit S.\&Rusch K. A. 2008. Design and implementation of a continuous microwave heating system for ballast water treatment. Environmental Science \& Technology 42 (11): 4121-4127.

[5] Gollasch S., David M., Voigt M., Dragsund E., Hewitt C.\&Fukuyo Y. 2007. Critical review of the IMO international convention on the management of ships' ballast water and sediments. Harmful Algae 6 (4): 585-600.

[6] Martinez L. F., Mahamud M. M., Lavin A. G.\&Bueno J. L. 2013. The regrowth of phytoplankton cultures after UV disinfection. Marine Pollution Bulletin 67 (1-2): 152-157. 
[7] Stehouwer P. P., Buma A.\&Peperzak L. 2015. A comparison of six different ballast water treatment systems based on UV radiation, electrochlorination and chlorine dioxide. Environmental Technology 36 (15): 2094-2104.

[8] Tsolaki E.\&Diamadopoulos E. 2010. Technologies for ballast water treatment: a review. Journal of Chemical Technology and Biotechnology 85 (1): 19-32.

[9] Wu D. H., You H., Du J. X., Chen C. A.\&Jin D. R. 2011. Effects of UV/Ag-TiO $/ 2 \mathrm{O}_{3}$ advanced oxidation on unicellular green alga Dunaliella salina: Implications for removal of invasive species from ballast water. Journal of Environmental Sciences-China 23 (3): 513-519. 